\title{
Household Attitudes towards Sustainable Management of Urban Green Spaces and Parks in Lagos State, Nigeria
}

\author{
0. C. Ajewole \\ Department of Agricultural Economics and Extension Services, \\ Ekiti State University, Ado-Ekiti, Nigeria \\ G. M. Adebo \\ Department of Agricultural Economics and Extension Services, \\ Ekiti State University, Ado-Ekiti, Nigeria \\ B. O. Fadipe \\ Department of Agricultural Economics and Extension Services, \\ Ekiti State University, Ado-Ekiti, Nigeria
}

\begin{abstract}
The attitude of urban dwellers is essential to the sustainable management of green spaces and parks in their environment. The study was carried out to examine various ways of raising fund, preferred mode of contribution and determinants of mode of contribution of the respondents to sustainable management of urban green spaces and parks. A total of 120 respondents were purposively selected based on the existence of green spaces and parks in six local government areas of Lagos state, Nigeria, Frequency counts, percentages and multivariate Probit regression model were used to analyze the data. The result shows that voluntary donations and Tax were rated by $40.8 \%$ of the respondents respectively as the most viable way of generating funds for sustainable management and maintenance of urban green spaces and park in Lagos state. Also, $46.67 \%$ of the respondents were willing to donate or pay cash as their means of contributing to sustainable management of green spaces and parks, while $6.67 \%$ were not willing to donate or render any assistance for sustainable management of green spaces and parks. The study affirmed that the Sex, Marital status, and average monthly income of the respondents had positive and significant influence on the respondents' contribution to sustainable management of urban green space and parks, while educational level had a negative influence on the mode respondents' contribution to sustainable management of green spaces and parks.
\end{abstract}

Keywords: Urban dwellers, Ecosystem services, Sustainability, Green spaces, Urban Parks, Lagos state.

\section{INTRODUCTION}

The promotion of green space and parks in the urban built environment was motivated by the challenges of global warming, rapid depletion of the ozone layer, and changes in the ecology of urban environment. This was occasioned by increasing population, overcrowded habitations and uncontrolled exploitation of natural resources which poses significant threat to life (Hales, 2000). The significance of green spaces and parks could be viewed with several lenses. Socially, green spaces create avenues for recreation, support the development of children, as well as social interaction and cohesion (Cohen, Inagami, and Finch, (2008); Jim and Chen, (2006); Isenberg, and Quisenberry, (2002). In essence, green spaces according to Haq (2011) helps to reduce social isolation, generate social capital, and lead to greater personal resilience and wellbeing. It could be of great significant to retirees and the elderly people. 
Physically, the availability of urban green spaces influences the likelihood and frequency of physical activities and an active lifestyle (Andrew, Jordan, and Horsley (2015). According to Coombes, Jones, Hillsdon (2010), urban green space may lower the likelihood of being overweight or obese. It may provide therapeutic spaces for rehabilitative exercise, such as for persons with coronary artery disease (Grazuleviciene, Vencloviene, 2008) According to Andrew (2008), Jordan, and Horsley, (2015) Urban green space and parks have direct health benefits by providing urban residents spaces for physical activity and social interaction, and allowing psychological restoration to take place.

In the economic realm, green spaces enhance property values, create job opportunities, , and generate revenues to augment government expenditure (Aldous,2005; Lutzenhiser, and Netusil, 2001, Crompton, 2001).

Environmentally, urban green spaces ameliorate local climate, improves urban air quality, conserve biodiversity and epitomize architectural beauty of cities (Fam, Mosley, Lopes, Mathieson, Morison, and Connellan, 2008, Nowak, Crane, and Stevens, 2006, Baycan-Levent and Nijkamp, 2009). According to Andrew, Jordan, and Horsley (2015), urban green spaces provide environmental benefits through their effects on negating urban heat, offsetting greenhouse gas emissions, and attenuating storm water. The environmental condition of a city often determines the ability of such city to function as a place of relaxation and opportunity. Graham, Gurian, Corella-Barud and Avitia-Diaz, (2004) stated that that rapid urbanization is significantly transforming the spatial pattern of urban land-use worldwide and is one of the most significant environmental problems facing many cities globally. Lack of green spaces in urban settings has contributed to the problems and issues related to urban pollution, heat island, erosion and flood (Omar, Ali, Latif, Lihan, and Adam, 2000).

In recent times, Lagos state, one of the fastest growing cities in the world witnessed a massive landscaping and beautification that has changed the face of the megacity for the better. According to the official website of the State, the "Operation Green Lagos" programme has resulted in the reclamation of open spaces from garbage, illegal structures and miscreants for city greening programme. These, according to Umunna (2010) as quoted by Olaleye (2013) has dramatically improved the aesthetic appeal of the environment and contributed to the global war against climate change.

Despite the recognition of the important roles and contributions of urban green spaces and parks to city development and prosperity in many African nations, the general attitude in green space planning is, often expressed solely through spontaneous action and direct intervention to a pressing problem (source, yr). Hence, putting green space planning into practice remains a significant challenge, and the practice of integrating green spaces and parks to urban development needs to be firmly supported by all stakeholders. The National Housing Policy (NHP) in Nigeria launched specified strategies for the maintenance and sustainability of formal parks, gardens, open spaces, greens, trees and general landscaping elements to enhance ecological balance (FMLHUD, 2012). The policy also ensures that they are not converted for other uses.

However, it is noted that not all successive governments in Nigeria adhere to the implementation of state policies met on ground while assuming office. Hence, there is the need to ensure the sustainability of Operation Lagos Green programme. Lessons from the developed economies are pointers to the fact that the sustainability of green space and parks should involve all stakeholders, rather than the government alone. It is against this backdrop that the study is embarked upon to explore the attitudes of urban households towards sustainable 
corporate management of urban green spaces and parks in Lagos state, Nigeria. It is hoped that the effort will make it easy for individuals, policymakers and international bodies to come into grips with the pertinent issues militating against the successful development and sustainable maintenance of green spaces in Nigeria and Lagos State in particular and hence, contribute in diverse ways to avert the situation.

\section{METHODOLOGY}

This study was carried out in Lagos State, Nigeria. Geographically, Lagos State is located at approximately latitude $6^{\circ} 24^{\prime}$ and $6^{\circ} 31^{\prime}$ North of equator and longitude $3^{\circ} 16^{\prime}$ and $3^{\circ} 27^{\prime}$ East of the Greenwich Meridian. The State is bounded in the East and North by Ogun State, in the West by the Republic of Benin and in the South by the Atlantic Ocean. Lagos State covers an area of $3,677 \mathrm{~km}^{2}$ with a total population of 9,113,605 (NPC, 2006). It has the highest population density of 2,451 persons per square kilometer in Nigeria. The climate in Lagos is similar to that of the rest of South Western Nigeria. There are two rainy seasons, with the most torrential rains falling from April to July and a lighter rainy season in October and November. There is a brief relatively dry spell in August and September and a longer dry season from December to March. The monthly rainfall between May and July averages over $300 \mathrm{~mm}$ (12 inches), while in August and September it is down to $75 \mathrm{~mm}$ (3inches) and in January as low as $35 \mathrm{~mm}$ (1.5 inches). The primary dry season is accompanied by harmattan winds from the Sahara Desert, which is between December and early February, and can be quite substantial. According to BBC Weather, the average temperature in January is $27{ }^{\circ} \mathrm{C}(79 \stackrel{\circ}{\circ})$, while that of July is $25{ }^{\circ} \mathrm{C}(77$ of). On the average, the hottest month in Lagos state is March, with a mean temperature of 29 ${ }^{\circ} \mathrm{C}\left(84^{\circ} \mathrm{o}\right)$, while the coldest month is July.. A two-stage-stage sampling procedure was used to select respondents for the study The first stage involves a purposive selection of six local government areas in Lagos State based on the existence of green spaces and parks. The local government areas (LGA)s selected includes Lekki LGA, Lagos Island LGA, Ikeja LGA, Apapa LGA, Badagry LGA and Eti-Osa LGA. The second stage involves a random selection of twenty respondents around the green spaces and park. In all, a total of one hundred and twenty respondents were selected and interviewed for the study. Data were obtained using a pretested structured questionnaire Descriptive statistics such as means, frequency counts, percentages, were used to describe and categorize the social-economic characteristics of the respondents, suggested ways of sustainable maintenance of green space and parks, and forms of the contribution of respondents. The multivariate Probit regression model was used to examine the determinants of respondents' mode of contribution towards sustainable management of urban green spaces and parks in Lagos state. The multivariate Probit regression model is described in terms of correlated multivariate normal distribution of the latent variables that are manifested as discrete variables through a threshold specification and hence allows the flexible modelling structure and easy interpretation of parameters The Multivariate Probit regression model used in this study is specified as linear combinations of a deterministic and stochastic component as follows;

Given that 'I' denotes the underlying latent response associated with $j$ th mode of contribution

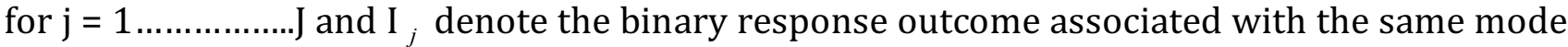
of contribution. $\mathrm{I}_{j}=1$ if the respondent indicates the mode of contribution and 0 otherwise. Therefore the multivariate Probit regression model may be specified as linear combinations of deterministic and stochastic components as follows; 


$$
\begin{array}{lll}
\mathrm{I}_{1}^{0}=\mathrm{x}^{\prime} \beta_{\mathrm{i}}+\varepsilon_{1} & \text { for } \mathrm{I}_{1}=\mathrm{I} & \left(\mathrm{I}_{1}^{0}>0\right) \\
\mathrm{I}_{2}^{0}=\mathrm{x}^{\prime} \beta_{2}+\varepsilon_{2} & \text { for } \mathrm{I}_{2}=\mathrm{I} & \left(\mathrm{I}_{2}^{0}>0\right) \\
\cdot & & \\
\cdot & \cdot & \\
\mathrm{I}_{j}^{0}=\mathrm{x}^{\prime} \beta_{j}+\varepsilon_{j} & \text { for } \mathrm{I}_{j}=\mathrm{I} & \left(\mathrm{I}_{j}^{0}>0\right)
\end{array}
$$

Where; $\mathrm{x}=\left(1, \mathrm{x}_{1} \ldots \ldots \ldots \ldots . . . \mathrm{x}_{n}\right)$ is a vector of $\mathrm{n}$ covariates which do not differ for each mode of contribution (i.e. the deterministic component) and $\beta_{\mathrm{j}}=\left(\begin{array}{llll}\beta_{\mathrm{j} 0} & \beta_{\mathrm{j} 1} & \ldots \ldots \ldots \ldots \ldots \ldots . . . \ldots & \beta_{\mathrm{j}_{n}}\end{array}\right)$ is a corresponding vector of parameters.

\section{RESULTS AND DISCUSSIONS}

The result in Table 1 shows that $75.8 \%$ of the respondents were male, while $24.2 \%$ were female. The mean age of the respondents was 30.10 years. The respondent's average monthly income was N48, 000.00. Also, 32.5\% of the households had between 1-3 members, $51.7 \%$ had between 4-6 members, while 15.8\% had between7-9 household members. The mean household size was 4.52 persons, an indication that the respondents household sizes was moderate. From the result $49.2 \%$ of respondents were living in house less than $10 \mathrm{~km}$ to their closest park, $45 \%$ of the respondents were living between $10 \mathrm{~km}-20 \mathrm{~km}$ from the park, and $5.9 \%$ of the respondents were living beyond $20 \mathrm{~km}$ from the park. This is stressing the stance of Lagos state government of ensuring green spaces are closer to dwellers than ever before(Awolowo, 2018)., Also, 56.7\% of the respondents were single while $43.3 \%$ of them were married total respondents. Observation shows that both single and married couples visit Parks and green spaces. In terms of education, 3.3\% of the respondents has no formal education, $25.8 \%$ had secondary education while $66.7 \%$ had tertiary education. It shows that most of the respondents interviewed on parks and green spaces were literates. The high literacy level is expected to influence their attitude towards the maintenance and sustainability of parks and green spaces. 
Table 1: Socioeconomic Characteristics of the respondents $\quad \mathrm{N}=120$

\begin{tabular}{|c|c|c|c|c|}
\hline Variables & Frequency & Percentage & Mean & Std. Dev. \\
\hline \multicolumn{5}{|l|}{ Sex } \\
\hline Male & 91 & 75.8 & & \\
\hline Female & 29 & 24.2 & & \\
\hline \multicolumn{5}{|l|}{ Age (Years) } \\
\hline$<30$ & 77 & 64.2 & 30.10 & 6.48 \\
\hline $30-40$ & 32 & 26.7 & & \\
\hline $41-50$ & 9 & 7.5 & & \\
\hline$>50$ & 2 & 1.7 & & \\
\hline Minimum & 20 & & & \\
\hline Maximum & 52 & & & \\
\hline \multicolumn{5}{|l|}{ Monthly Income (N) } \\
\hline$<15000$ & 2 & 1.7 & 48800 & 2935.08 \\
\hline $15000-40000$ & 52 & 43.3 & & \\
\hline $41000-60000$ & 43 & 35.8 & & \\
\hline $61000-80000$ & 14 & 11.7 & & \\
\hline $81000-100000$ & 9 & 7.5 & & \\
\hline Minimum & 15000 & & & \\
\hline Maximum & 100000 & & & \\
\hline \multicolumn{5}{|l|}{ Household Size } \\
\hline $1-3$ & 39 & 32.5 & 4.52 & 1.918 \\
\hline $4-6$ & 62 & 51.7 & & \\
\hline $7-9$ & 19 & 15.8 & & \\
\hline Minimum & 1 & & & \\
\hline Maximum & 9 & & & \\
\hline \multicolumn{5}{|c|}{ Distance To Nearest Parks (Km) } \\
\hline$<10$ & 59 & 49.2 & 13.66 & 7.144 \\
\hline $10-20$ & 54 & 45.0 & & \\
\hline $21-30$ & 5 & 4.2 & & \\
\hline $31-40$ & 2 & 1.7 & & \\
\hline Minimum & 2 & & & \\
\hline Maximum & 40 & & & \\
\hline \multicolumn{5}{|l|}{ Marital Status } \\
\hline Married & 52 & 43.3 & & \\
\hline Single & 68 & 56.7 & & \\
\hline \multicolumn{5}{|l|}{ Educational Level } \\
\hline No Education & 1 & 0.8 & & \\
\hline Adult Education & 1 & 0.8 & & \\
\hline Primary Education & 2 & 1.7 & & \\
\hline Secondary Education & 31 & 25.8 & & \\
\hline Tertiary Education & 80 & 66.7 & & \\
\hline Others & 5 & 4.2 & & \\
\hline
\end{tabular}

Source: Field Survey, 2017.

\section{Perceived ways of Sustainable Maintenance of Urban Green Spaces and Parks}

Table 2 shows the distribution of perceived ways of sustainable maintenance of parks by respondents. A total of 49 respondents representing $40.8 \%$ of sampled respondents support contribution to sustainable maintenance through voluntary donations and tax payment respectively. Seven respondents representing 5.8\% of total respondents' support contribution towards sustainable maintenance through levies and appealing to cooperate organizations 
respectively. 21 respondents representing $17.5 \%$ of the total respondents support contribution towards the sustainable maintenance of parks through commercialization of the parks. 28 respondents representing $23.3 \%$ of the total respondents support contribution to the sustainable maintenance of parks by encouraging green spaces and parks acquisition by individual cooperate bodies or Non-Governmental Organizations (NGOs).

Table 2: Distribution of Perceived ways of Sustainable Maintenance of Parks

\begin{tabular}{lcc}
\hline Perceived ways & *Frequency & Percent \\
\hline Voluntary donation & 49 & 40.8 \\
Taxes & 49 & 40.8 \\
Levies & 7 & 5.8 \\
Commercialization of the parks & 21 & 17.5 \\
Appealing to cooperate Organization & 7 & 5.8 \\
Encourage green spaces and parks acquisition & & \\
by individual cooperate bodies or NGOs & 28 & 23.3 \\
\hline
\end{tabular}

*Multiple responses recorded

\section{Distribution of Respondents Mode of Contribution}

This section deals with the respondents' mode of contribution towards the sustainable management of urban green spaces and parks in the study area. Table 3 shows the distribution of indicated forms of the contribution of respondents, , $6.67 \%$ of the respondents are not willing to contribute anything towards sustainable management of urban green spaces and parks in Lagos state. Out of the $93.3 \%$ that indicates a willingness to contribute towards sustainable management of urban green spaces and parks, $46.67 \%$ are willing to contribute cash while $12.50 \%$ are willing to contribute in kind; (such as donating materials, equipment and other facilities for the upkeep of the green spaces and parks). Also, $34.16 \%$ are willing to offer voluntary services to clean up the spaces and other services required towards sustainable management of urban green spaces and parks.

Table 3: Distribution of forms of the contribution of respondents

\begin{tabular}{lcc}
\hline A form of contribution & Frequency & Percent \\
\hline NONE & 8 & 6.67 \\
CASH & 56 & 46.67 \\
KIND & 15 & 12.50 \\
SERVICE & 41 & 34.16 \\
Total & 120 & 100 \\
\hline
\end{tabular}

Source: Field Survey, 2017.

\section{Determinants of Respondents' mode of contribution towards sustainable management of urban green spaces and parks in Lagos state.}

The result of the multivariate Probit regression analysis used to estimate the determinants of Respondents' attitude towards sustainable management of Urban green spaces and parks in Lagos state is presented below in Table 4. The coefficient of sex is positive and significant $(p<0.01)$ for respondents willingness to contribute cash towards sustainable management of urban green spaces and parks in Lagos. It shows that males are willing to contribute cash more than the females towards sustainable management of urban green spaces and parks in Lagos state. Also, the coefficient of sex is positive and significant $(\mathrm{p}<0.05)$ for respondents willing to render voluntary services towards sustainable management of urban green spaces and parks in Lagos state. It shows that more males than female respondents are willing to render voluntary towards sustainable management of urban green spaces and parks. Also, the 
coefficient of the age of respondents is positive and significant $(p<0.10)$ for respondents willing to contribute in-kind towards sustainable management of the urban green spaces and parks. It indicates that a unit increase in age of respondents will increase their tendency to contribute by kind towards sustainable management of urban green spaces and parks in Lagos state.

The coefficient of marital status is positive and significant $(p<0.01)$ for respondents willing to contribute in kind towards sustainable management of the urban green spaces and parks. It shows that married respondents have a higher tendency of contributing in kind than single respondents towards sustainable management of urban green spaces and parks. Also, the coefficient of marital status is positive and significant $(\mathrm{p}<0.05)$ for respondents willing to contribute by rendering service or services towards sustainable management of urban green spaces and parks in Lagos state. It shows that married respondents have a higher tendency of rendering voluntary services than singles towards sustainable management of urban green spaces and parks in Lagos state. The coefficient of educational level is negative and significant $(p<0.05)$ for respondents willing to contribute by cash to the sustainable management of the urban green spaces and parks. It indicates that an increase in the level of education of respondents will limit their willingness to contribute cash towards sustainable management of the urban green spaces and parks in Lagos state. Also, the coefficient of educational level is negative and significant $(\mathrm{p}<0.05)$ for respondents willing to render voluntary services towards sustainable management of the urban green spaces and parks. It shows that an increase in the level of education of respondents will reduce respondents' willingness to render voluntary services towards sustainable management of urban green spaces and park in Lagos state.

Table 4: Determinants of Respondents' mode of Contribution towards sustainable management of urban green spaces and parks in Lagos state.

\begin{tabular}{lllllll}
\hline Variables & \multicolumn{2}{c}{ Cash } & \multicolumn{2}{c}{ Kind } & \multicolumn{2}{c}{ Service } \\
\hline Sex & Coeff & $\mathrm{P}>|\mathrm{z}|$ & Coeff & $\mathrm{P}>|\mathrm{z}|$ & Coeff & $\mathrm{P}>|\mathrm{z}|$ \\
Age & $2.9872^{* * *}$ & 0.008 & 1.5827 & 0.232 & $2.7096^{* *}$ & 0.019 \\
Ms & 0.2816 & 0.184 & $0.3613^{*}$ & 0.098 & $0.3751^{*}$ & 0.080 \\
Hs & 1.4992 & 0.343 & $23.5463^{* * *}$ & 0.000 & $3.3644^{* *}$ & 0.038 \\
Edulev & -0.2363 & 0.563 & 0.5191 & 0.279 & -0.2620 & 0.525 \\
Avmi & $-3.0228^{* *}$ & 0.017 & -0.4145 & 0.853 & $-2.7903^{* *}$ & 0.029 \\
Dist & 0.0003 & 0.172 & -0.003 & 0.287 & 0.0003 & 0.186 \\
How & 0.1673 & 0.127 & 0.1408 & 0.199 & 0.1656 & 0.131 \\
\hline
\end{tabular}

(fcon $=0$ is the base outcome, i.e. no form of contribution is the base outcome)

Number of obs $=120$

$\operatorname{LR} \operatorname{chi}^{2}(24) \quad=88.26$

Prob $>$ chi $^{2}=0.0000$

Log likelihood $=-95.4383$

Pseudo R $\mathrm{R}^{2} \quad=0.3162$

\section{CONCLUSION}

This research was conducted to investigate the perception of households towards sustainable management of urban green spaces and parks, their willingness and mode of contribution towards the sustainability of green spaces and parks, and the determinants of the respondents' willingness to contribute towards the sustainable management of urban green spaces and parks in Lagos state, Nigeria.. The results of the study indicate a vast majority $93.3 \%$ of the respondents are willing to contribute in one form or the other towards the sustainable management of urban green spaces and parks in Lagos state. Also, factors that significantly influence the mode of the contribution of the respondents positively are sex, marital status, 
and average monthly income while education level was significant and negatively influenced the mode respondents' contribution to sustainable management of green spaces and parks in the study area.

\section{RECOMMENDATIONS}

Based on the findings of the study, the study recommends that government should formulate a policy that will enable them to leverage on the willingness of the respondents to contribute in cash, kind as well as rendering voluntary services to maintain and sustain, the urban green spaces and parks in Lagos state. It will relieve the government of the financial burden of effectively managing the green spaces and park.

\section{References}

Aldous, D. E., 2005, Education and training opportunities for turf management in Australia. Acta Horticulture, 672, 71-7.

Baycan-Levent, T., and Nijkamp, P., 2009, Planning and management of urban green spaces in Europe: Comparative analysis. Journal of Urban Planning and. Development., 135(1), 1-12.

Cohen, D. A., Inagami, S., and Finch, B., 2008, The built environment and collective efficacy. Health \& Place, 14, 198-208.

Crompton, J. L., 2001, The Impacts of parks on property values: A review of the empirical evidence. Journal of Leisure Research, 33(1), 1-31.

Fam, D., Mosley, E., Lopes, A., Mathieson, L., Morison, J., and Connellan, G., (2008): Irrigation of urban green spaces: A review of the environmental, social and economic benefits. CRC for Irrigation Futures Technical Report No. 04/08.

Federal Ministry of Land, Housing and Urban Development (FMLHUD) (2012): Report of the 2nd Meeting of Officials of the National Council of Lands, Housing, and Urban Development, Port-Harcourt, Nigeria, 2012.

Graham, J. Gurian, P. Corella-Barud V. and Avitia-Diaz, R. (2004). Peri-urbanization and in home environmental health risks: the side effects of planned and unplanned growth, International Journal of Hygiene and Environmental Health 207 pp. 447-454.

Hales, D.F. (2000). Practical Steps toward Healthier Cities and a Cleaner Global Environment. Global Issues-An Electronic Journal of the U.S. Department of State 5(1):11-16.

Isenberg, J. P., and Quisenberry, N., (2002): Play: Essential for all children. A position paper for the Association for Childhood Education International.[Online].

Available:http://365waystounplugyourkids.com/play_Essential_for_kidsl.htm.

Jim, C.Y., and Chen, W. Y., (2006): Recreation-Amenity Use and Contingent Valuation of Urban Green Spaces in Guangzhou, China. Landscape and Urban Planning, 75, 81-96.

Lutzenhiser, M., and Netusil, N., (2001). The effect of open space on a home's sale price. Contemporary Economic Policy, 19(3), 291-298.

Malmström, S, Györki, I, Sjögren, P.A (1991); Bonniers svenska ordbok [Bonnier's Swedish Dictionary]. Bonniers Fakta Bokförlag AB, Stockholm.

Nowak, D. J., Crane, D. E., and Stevens, J. C. (2006). Air pollution removal by urban trees and Shrubs in the United States. Urban Forestry \& Urban Greening, 4(3-4), 115-23.

National Population Commission (NPC) (2006). Official Census Report, Abuja, Nigeria.

Olaleye D.O.(2013): Community Greening in Pre and Post Climate Change Knowledge The era in Third World Cities: Case Study of Lagos, Nigeria. Civil and Environmental Research Vol.3, No.7 .www.iiste.org

Omar R., Ali R.Z., Latif M.T., Lihan T., Adam J.H. (2000): Natural Resources. Proceedings of The Regional Symposium on Environ. Kuala Lumpur, Malaysia. Vol. 1: 261-269.

Popoola, A.A Medayese, S.O., Olaniyan, O.M, Onyemenam, P.I and Adeleye, B.M (2016): Users' Perception of Urban Parks and Green Networks in Ibadan. Singaporean Journal of Business Economics, and Management Studies Vol.4, No. 10,

Andrew Chee Keng Lee, Hannah C Jordan, and Jason Horsley (2015). Value of urban green spaces in promoting healthy living and wellbeing: prospects for planning .Risk Manag Healthc Policy 8. PMC4556255

https://www.ncbi.nlm.nih.gov/pmc/articles/PMC4556255/. 
Ajewole, O. C., Adebo, G. M., \& Fadipe, B. O. (2019). Household Attitudes towards Sustainable Management of Urban Green Spaces and Parks in Lagos State, Nigeria. Advances in Social Sciences Research Journal, 6(8) 58-66.

Haq SM. Urban green spaces and an integrative approach to sustainable environment. J Environ Protect. 2011;2(5):601-608.

Coombes E, Jones AP, Hillsdon M. The relationship of physical activity and overweight to objectively measured green space accessibility and use. Soc Sci Med. 2010;70(6):816-822. [PMC free article] [PubMed]

Grazuleviciene R, Vencloviene J, Kubilius R, et al. The effect of park and urban environments on coronary artery disease patients: a randomized trial. BioMed Res Int. 2008;2008:403012. [PMC free article] [PubMed] 